\title{
Phytopharmacological Study of Piper Betle Leaf
}

\author{
Nishant M Patel", Darshankumar D. Jain, Hemant P. Suryawanshi, Sunil P Pawar
}

P.S.G.V.P.M's College of Pharmacy, Shahada (MS), India

\author{
DOI: $10.36348 /$ sjmps.2019.v05i11.008 \\ | Received: 07.11.2019 | Accepted: 14.11.2019| Published: 16.11.2019 \\ *Corresponding author: Mr. Nishant Mahendra Patel
}

\section{Abstract}

Piper betle $L$. is an evergreen perennial dioecious creeper and it is native to Malaysia. It is commonly used in our day to day life. In present investigation an attempt has been made for the pharmacognostic standardization and phytochemical evaluation of Piper betle L. leaves. The pharmacognostic evaluation comprises of detailed morphology, powdered microscopy, quantitative microscopy and physical constants such as extractive and ash values. The leaves extract were subjected to preliminary phytochemical screening. The data obtained in present study will serve as valuable tool for identification, authentication and detection of adulterants standardization and quality control of the drug. In this research work the anthelmintic property of leaves extract of Piper betle L. belonging to family Piperaceae was studied for anthelmintic activity against Pheretima Posthuma (Indian earthworm). The leaves powder of Piper betle $L$. was subjected to successive extraction by maceration using solvents like Aqueous, Acetone + Aqueous and Pet. Ether. Four concentrations (25, 50, 75 and $100 \mathrm{mg} / \mathrm{ml})$ of different extract of leaves were studied in a bioassay, which involved the determination of time of paralysis and time of death of the worms. $100 \mathrm{mg} / \mathrm{ml}$ conc. of Aqueous + Acetone extract of leaves of Piper betle L. reveal considerable anthelmintic activity as compared to other two concentrations and piperazine citrate $(10 \mathrm{mg} / \mathrm{ml})$. Piperazine citrate and saline water were included in the assay as standard reference drug and control, respectively.

Keywords: Piper betle, Phytochemistry, Anthelmintic activity, Pheretima Posthuma etc.

Copyright @ 2019: This is an open-access article distributed under the terms of the Creative Commons Attribution license which permits unrestricted use, distribution, and reproduction in any medium for non-commercial use (NonCommercial, or CC-BY-NC) provided the original author and source are credited.

\section{INTRODUCTION}

Piper betle L. (Piperaceae) is an evergreen perennial dioecious creeper and It is commonly known as 'Paan' or 'Nagvalli'[1]. From ancient time betel are chewed along with areca nut, slaked lime, cardamom and clove in many Asian countries and offering betel morsel (Pan-Supari) to guests in Indian subcontinent is a common courtesy [2]. This plant is extensively grown in Bangladesh, India, Sri Lanka, Malaysia, Thailand, Taiwan and other Southeast Asian countries [3]. Recently, the medicinal uses and properties of areca nut were investigated. It has antimicrobial [4], antifertility [5], antihyperglycemic [6], antidermatophytic [7] antinociceptive [8] analgesic activity [9]. In spite of all these medicinal values of Piper betle $L$, its chronic consumption or chewing may cause several adverse effects including carcinogenesis.

\section{Taxonomical classification [10] \\ - Kingdom : Plantae \\ - Order : Piperales \\ - Family : Piperaceae \\ - Subfamily : Piperoideae}

- Genus : Piper

- Species : Piper betle L

- Division : Magnoliphyta

Local names [11]
$\begin{array}{lll}\text { - } & \text { Marathi } & \text { : Nagabael } \\ \text { - } & \text { Hindi } & \text { : Paan } \\ \text { - } & \text { Sanskrit } & \text { : Tambool } \\ \text { - } & \text { Malayalam } & \text { : Vettila } \\ \text { - } & \text { Kannada } & \text { : Eleballi } \\ \text { - } & \text { Gujarati } & \text { : Nagarbael } \\ \text { - } & \text { Tamil } & \text { : Vetrilai } \\ \text { - } & \text { Bengali } & \text { : Paan } \\ \text { - Telgu } & \text { : Nagballi } \\ \text { - } & \text { English } & \text { : Betel-vine }\end{array}$

Description of Plant

Is a perennial dioeciously creeper. Stems are semi woody, climbing by means of short adventitious roots. Leaves are 10-20 cm long, broadly ovate, slightly cordate and often unequal at the base, shortly acuminate, glabrous, and glaucous on sides, bright green or yellowish, petiole stout $2.0-2.5 \mathrm{~cm}$ long. The 
Male spikes are cylindrical dense. Female spikes 2.5$5.0 \mathrm{~cm}$ long, pendulous. Fruits rarely produced, often sunk in the fleshy spike, forming nodule-like structures.

The branches of the plant are swollen at the nodes. The plant has alternate, heart-shaped, smooth, shining and long-stalked leaves, with pointed apex [12].

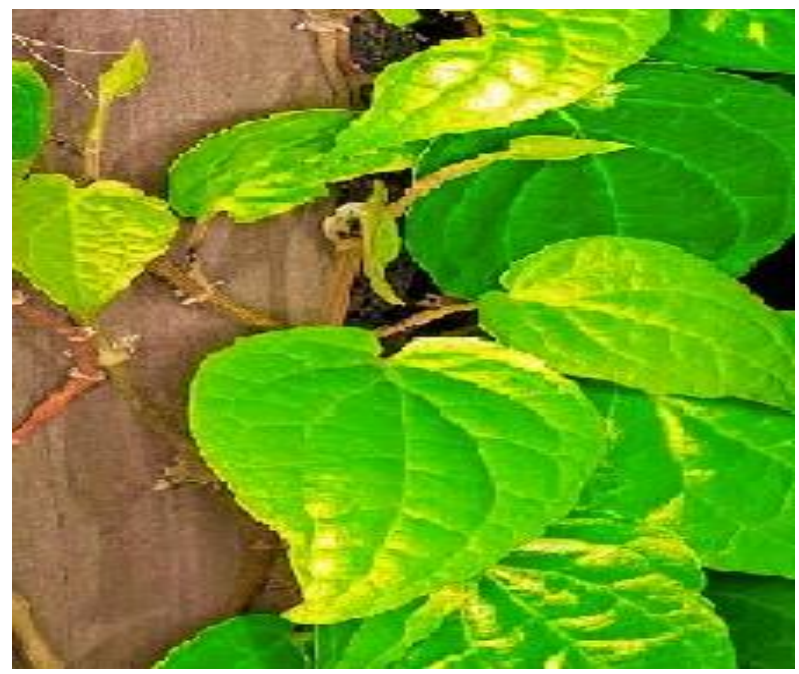

Fig-1: Creeper of Piper betel L [13]

\section{Chemical Constituents}

Piper betle L. leaf has been described to have piperol-A, piperol-B, methyl piper betlol and they also have been isolated. Piper betel leaves have an essential oil composing of terpinen-4-ol, safrole, allylpyrocatecholmonoacetate, eugenol, eugenyl acetate, hydroxyl chavicol, eugenol, piper betol and the betel oil contains cadinenecarvacrol, allyl catechol, chavicol, pcymene, caryophyllene, chavibetol, cineole and estragolas the major components [14-16].

\section{Cultivation and collection $[10,11]$ Propagation}

- Propagation is easy by root division or cuttings. Betel requires well-drained fertile soil semi-shade position. Waterlogged, saline and alkali soils are unsuitable for its cultivation.

\section{Cultivation}

- First of all prepare a garden called a barouj in which to grow betel. The barouj is fenced with bamboo sticks and coconut leaves.

- The soil is plowed into furrows of 10 to 15 meter length, $75 \mathrm{~cm}$ in width and $75 \mathrm{~cm}$ in depth.

- Oil cakes, manure and leaves are thoroughly incorporated with the topsoil of the furrows and wood ash. The cuttings are planted at the beginning of the monsoon season.

- Proper shade and irrigation are essential for the successful cultivation of this crop. Betel needs constantly moist soil, but there should not be excessive moisture. Irrigation is frequent and light and standing water should not remain for more than half an hour.

\section{Collection}

- In 3 to 6 months the vines reach 150 to 180 centimeters in height and they will branch.

- Harvest begins, with the farmer plucking the leaf and its petiole with his right thumb.

- The harvest lasts 15 days to one month.

\section{MATERIAL AND METHODS \\ Procurement of Plant Material}

The leaves of Piper betle $L$. have been collected from the local region of Shahada. The plant is authenticated by Dr. Santosh Tayade, Dept. of Botany, ASC College, Lonkheda, Shahada, Nandurbar (M.S). The voucher specimen has been preserved in the laboratory for future reference in the Dept. of Pharmacognosy and Phytochemistry, COP, Shahada.

The collected plant material was air dried and used for the study of macroscopic and microscopic characters. Finally dried leaves were subjected to size reduction to get coarse powder and then passed through sieve no. 40 to get uniform powder. Then uniform powder was subjected for the determination of ash values, extractive values, and loss on drying and phytochemical constituents.

\section{Pharmacognostic evaluation Organoleptic Evaluation}

In organoleptic evaluation, various sensory parameters such as color, odour, taste, shape, apex, venation, and texture of the leaves were observed and shown in Table No.1.

\section{Microscopical Evaluation \\ T. S. of Piper betle L. leaves}

The T.S. of the Piper betle L. leaves were taken to observe microscopic characteristics Characteristic are shown in microscopic pictures as Fig. 2.

\section{Powder Analysis}

To a little quantity of powder taken onto a microscopic slide, $1-2$ drops of $0.1 \%$ phloroglucinol solution and a drop of concentrated hydrochloric acid were added, covered with a cover slip and observed under microscope with $10 \times 10$ magnification. The characteristic features of the powder like fiber, trichome, collenchyma cells, etc. were recorded using standard techniques. The characteristic are shown in microscopic pictures as Fig. 3, 4, and 5 respectively.

\section{Physical evaluation}

In physical evaluation, ash values viz., total ash, acid insoluble ash and water soluble ash, and 
extractive values viz., water soluble extractive and pet. Ether extractive values were determined.

\section{Determination of ash values [17] Total Ash Value}

Accurately weighed ( 2 g) of air-dried Piper betle $L$. leaves powder was taken in a silica dish and incinerated at a temperature not exceeding $450^{\circ} \mathrm{C}$ until free from carbon. The resultant ash was cooled and weighed. The $\%$ of ash was calculated with reference to the air dried drug.

\section{Acid Insoluble Ash}

The total ash obtained from (2 g) of Piper betle $L$. leaves powder was boiled for 5 minutes with 25 $\mathrm{ml}$ of dilute $\mathrm{HCl}$ and the insoluble matter was collected on an ash less filter paper. It was washed with hot water, ignited and weighed. The $\%$ of acid insoluble ash was calculated with reference to the air dried drug.

\section{Water Soluble Ash}

The total ash obtained from (2 g) Piper betle $L$. leaves powder was boiled for 5 minutes with $25 \mathrm{ml}$ of water, the insoluble matter was collected on an ash less filter paper, washed with hot water, and ignited for $15 \mathrm{~min}$ at a temperature not exceeding $450^{\circ} \mathrm{C}$. The weight of insoluble matter was subtracted from the weight of the ash, the difference in weight represent the water-soluble ash was calculated with reference to the air-dried drug.

\section{Extractive values [18]}

Pet. ether $\left(40\right.$ - $\left.60^{\circ} \mathrm{C}\right)$ soluble extractive value Accurately weighed $(5 \mathrm{~g})$ of leaves powder of Piper betle L. was macerated with $100 \mathrm{ml}$ of Petroleum ether in a closed flask, shaking frequently during the first 6 hours and allowed to stand for 18 hours. Thereafter, it was filtered rapidly taking precaution against loss of Petroleum ether. Evaporated $25 \mathrm{ml}$ of filtrate to dryness in a tarred flat bottom shallow dish dried at $105^{\circ} \mathrm{C}$ and weighed and $\%$ Petroleum ether soluble extractive was calculated with reference to the leaves.

\section{Water-soluble extractive value}

Accurately weighed $(5 \mathrm{~g})$ of leaves powder of Piper betle $L$. was added to $50 \mathrm{ml}$ boiled water at $80^{\circ} \mathrm{C}$ in a stoppered flask. It was then shaken well and allowed to stand for $10 \mathrm{~min}$ so as to cool it and filtered. $5 \mathrm{ml}$ of filtrate was transferred to an evaporating dish, which was $7.5 \mathrm{~cm}$ in diameter, the solvent was evaporated on water bath, allowed to dry for 30 minutes, finally dried in an oven for $2 \mathrm{hrs}$ At $100^{\circ} \mathrm{C}$ and residue was weighed $\%$ of water soluble extractive value was calculated with reference to the air dried drug.
Loss on drying [19]

Accurately weighed ( $2 \mathrm{~g})$ quantity of leaves powder of Piper betle $L$. was taken in tarred glass bottle and initial weight was taken. The sample was heated at $105^{\circ} \mathrm{C}$ in an oven and weighed. This procedure was repeated until a constant weight was obtained. The moisture content of the sample was calculated with reference to air-dried drug.

\section{Preliminary phytochemical screening [20]}

The leaves powder are subjected to successive extraction by maceration by using water + acetone, the extracts where evaporated to dryness. The dried extracts were weighed. The $\%$ yield of leaves of Piper betle $L$. after maceration was found to be max of 8.12.

\section{Phytoconstituents present in extract of leaves of Piper betle $L$}

The extract were used for preliminary phytochemical with a chemical tests viz., Molisch's, fehling's, Benedict's and Barfoed's tests for carbohydrates; Ninhydrin's test for amino acids; Salkowski and Libermann-Burchard's reaction for steroids; Foam test for saponin glycosides; Dragendorff's, Mayer's, Hager's and Wagner's tests for alkaloids; and ferric chloride, lead acetate, potassium dichromate, and dilute iodine tests for tannins, shinoda test for flavonoids The results are given below in Table No.5.

\section{Pharmacological evaluation Anthelmintic activity}

The anthelmintic assay was carried as per the method of Ajaiyeoba et al. with necessary modification [21]. The assay was performed on adult Indian earthworm, due to its anatomical and physiological resemble with the intestinal round worm parasite of human being [22, 23]. Because of easy availability, earthworm has been used widely for initial evaluation of anthelmintic compound in vitro [24]. $25 \mathrm{ml}$ of formulation containing different concentration of crude drug aqueous + acetone extract $(25,50,75,100 \mathrm{mg} / \mathrm{ml}$ in dist. water) were prepared and 4 worms of same type were placed in it. Time for paralysis was noted when no movement of any sort could be observed except when the worms were shaken vigorously. Time for death of worms were recorded after ascertaining that worms neither move when shaken vigorously nor when dipped in warm water $\left(50^{\circ} \mathrm{C}\right)$. Piperazine citrate $(10 \mathrm{mg} / \mathrm{ml})$ was used as reference standard while saline water as control.

\section{MATERIALS AND METHODS Plant Material}

The fresh leaves of Piper betle L. have been collected from the local area at Shahada and authentified by Dr. Santosh. K. Tayade, HOD of Botany, ASC College, Lonkheda, Shahada. 


\section{Worms}

Indian earthworms (Pheretima Posthuma) were used to study anthelmintic activity. The earthworms were collected from moist soil at local area at Taloda, Nandurbar. The average size of earthworm was $6-8 \mathrm{~cm}$. All worms were washed with normal saline,and kept in beakers containing normal saline separately.

\section{Preparation of Extracts}

Collected fresh leaves of Piper betle L. were dried and crushed to coarse powder and pass it through sieve no 40 to get fine powder and subject it to maceration with Aqueous + Acetone, and Pet. ether then dried it by using evaporator and then extract was subjected to preliminary phytochemical testing [25-27].
Drugs and chemicals

- Piperazine citrate.

- Saline solution.

\section{RESULTS}

In the present study leaves of Piper betle $L$. was evaluated for its pharmacognostic, phytochemical and pharmacological aspects which revealed the following results.

\section{Pharmacognostic evaluation \\ Organoleptic Evaluation}

The results of organoleptic evaluations were given in Table No. 1.

Table-1: Organoleptic/Macroscopic characteristics of leaves of Piper betle L.

\begin{tabular}{|c|l|l|}
\hline Sr. No. & Parameters & \multicolumn{1}{c|}{ Observation of Leaf } \\
\hline 1. & Colour & Yellowish Green -Dark Green \\
\hline 2. & Odour & Characteristic and pleasant \\
\hline 3. & Taste & Sweet to Pungent \\
\hline 4. & Shape & Heart shape \\
\hline 5. & Texture & Glossy, smooth \\
\hline 7. & Venation & Reticulate \\
\hline 8 & Apex & Pointed \\
\hline
\end{tabular}

\section{Microscopical Evaluation}

Transverse Section of Piper betle L. leaves

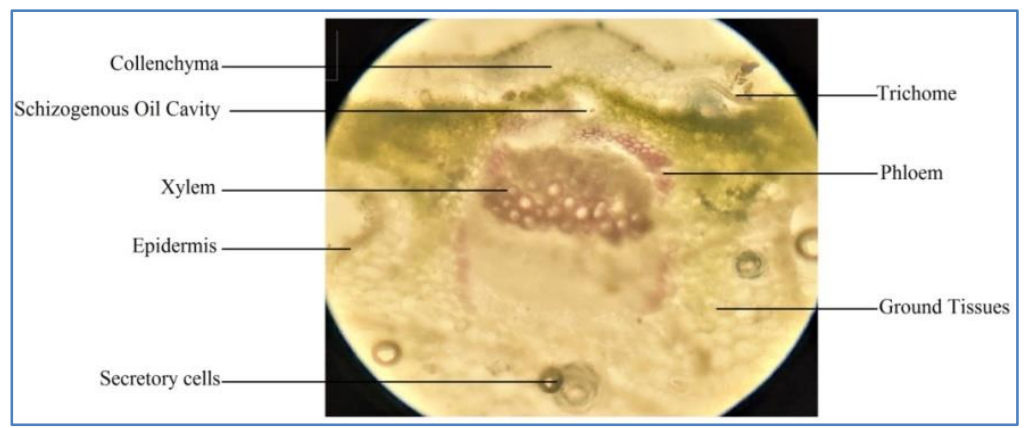

Fig-2: Transverse section of the leaves of Piper betle $L$.

The transverse section of the leaves of Piper betle L. (Fig. 2) shows the typical microscopic characteristics like epidermis, collenchyma, xylem, phloem, schizogenous oil cavity, ground tissues, secretory cell, trichome, etc. The characteristic are shown Table No. 2.
Table-2: Microscopic characteristic of transverse section of leaves of Piper betle $L$.

\begin{tabular}{|c|l|}
\hline Sr. No. & Observation of T. S of leaf \\
\hline 1. & Epidermis \\
\hline 2. & Collenchyma \\
\hline 3. & Xylem \\
\hline 4. & Phloem \\
\hline 5. & Schizogenous oil cavity \\
\hline 6. & Ground tissues \\
\hline 7. & Secretory cell \\
\hline 8. & Trichome \\
\hline
\end{tabular}




\section{Powder Analysis}

The powder of the leaves of Piper betle $L$. shows the typical microscopic characteristics like fibres, trichome and collenchyma cell etc. The characteristic are shown Table No. 3 and Fig. 3, 4 and 5 respectively.

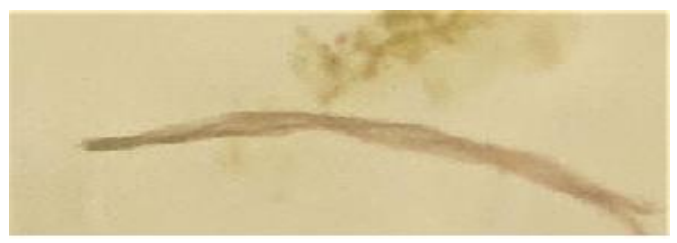

Fig-3: Fiber

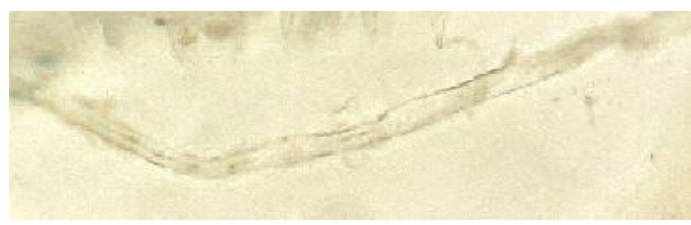

Fig-4: Trichome

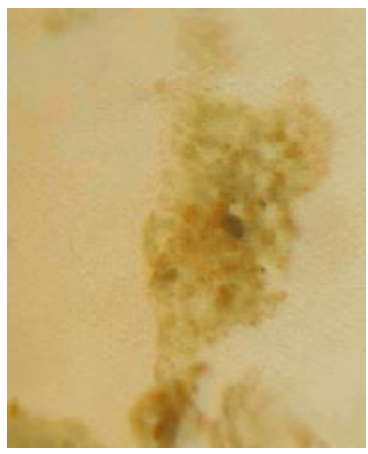

Fig-5: Collenchyma cells

Table-3: Microscopic characteristic of for leaves powder of Piper betle $L$

\begin{tabular}{|c|l|}
\hline Sr. No. & Observation of Piper betle $L$. powder \\
\hline 1. & Fibers \\
\hline 2. & Trichome \\
\hline 3. & Collenchyma cells \\
\hline
\end{tabular}

\section{Physical evaluation}

- Ash Values: The total cash value, acid insoluble ash value and water soluble ash value was found to be $3.1 \% \mathrm{w} / \mathrm{w}, 1.2 \% \mathrm{w} / \mathrm{w}$ and $1.9 \% \mathrm{w} / \mathrm{w}$ respectively as shown in Table No.4.

- Extractive Values: The water soluble and Petroleum ether soluble extractive values were found to be $3.9 \% \mathrm{w} / \mathrm{w}$ and $4.5 \% \mathrm{w} / \mathrm{w}$ respectively as shown in Table No.4.

- Loss on Drying: The loss on drying was found to be $0.80 \% \mathrm{w} / \mathrm{w}$ as shown in Table No.4.

Table-4: Physical constants for leaves powder of Piper betle $L$

\begin{tabular}{|c|c|c|}
\hline Sr. No. & \multicolumn{1}{|c|}{ Physical Constants } & Results \\
\hline & Ash Values & \\
1. & $\bullet \quad$ Total Ash & $3.1 \% \mathrm{w} / \mathrm{w}$ \\
& $\bullet \quad$ Acid Insoluble Ash & $1.2 \% \mathrm{w} / \mathrm{w}$ \\
& $\bullet \quad$ Water Soluble Ash & $1.9 \% \mathrm{w} / \mathrm{w}$ \\
\hline & Extractive Values & \\
2. & A) Water soluble extractive & $3.9 \% \mathrm{w} / \mathrm{w}$ \\
& B) Petroleum ether soluble extractive & $4.5 \% \mathrm{w} / \mathrm{w}$ \\
\hline 3. & Loss on Drying & $0.80 \% \mathrm{w} / \mathrm{w}$ \\
\hline
\end{tabular}

\section{Preliminary phytochemical screening}

The percentage yield of leaves of Piper betle $L$. after maceration was found to be $\max 8.12 \%$ as compared to other extracts

\section{Phytoconstituents present in aqueous + acetone extract of Piper betle $L$. leaves}

In the present investigation the extract of plant was analyzed for the presence of alkaloids, carbohydrates, glycosides, amino acids, steroids, tannins and flavonoids using standard procedures. The preliminary phytochemical investigation showed the presence of alkaloids, carbohydrates, saponins, tannins, steroids, glycosides, flavonoids and amino acids as shown in Table No. 5. 
Table-5: Data showing the presence of phytoconstituents present in aqueous + acetone extract of Piper betle L. leaves

\begin{tabular}{|l|l|l|}
\hline Sr. No & Phytoconstituents & Aqueous + Acetone extract \\
\hline $\mathbf{1}$ & Alkaloids & Present \\
A & Dragendorff's Reagent & + \\
B & Hager's Reagent & - \\
C & Wagner's Reagent & + \\
D & Mayer's Reagent & + \\
\hline $\mathbf{2}$ & Carbohydrate & Present \\
A & Molisch's test & + \\
B & Benedict's test & + \\
C & Fehling's test & + \\
\hline $\mathbf{3}$ & Saponins & Present \\
A & Foam test & + \\
\hline $\mathbf{4}$ & Tannins & Present \\
\hline $\mathbf{5}$ & Steroids & Present \\
A & Salkowski test & + \\
B & Libermann-Burchard's test & + \\
\hline $\mathbf{6}$ & Glycosides & Present \\
\hline $\mathbf{7}$ & Flavonoids & Present \\
A & Shinoda test & + \\
B & Lead acetate test & + \\
\hline $\mathbf{8}$ & Amino acids & Present \\
A & Ninhydrin's test & + \\
\hline
\end{tabular}

\section{Pharmacological evaluation}

Anthelmintic activity

Table-6: Anthelmintic activity of Piper betle L. leaves extracts on Indian earthworms (Pheretima Posthuma)

\begin{tabular}{|c|c|c|c|c|}
\hline \multirow[b]{2}{*}{ Sr. No. } & \multirow[t]{2}{*}{ Extracts } & \multirow{2}{*}{$\begin{array}{c}\text { Conc. } \\
\text { (in mg/ml) }\end{array}$} & \multicolumn{2}{|c|}{$\begin{array}{c}\text { Indian Earthworm } \\
\text { (Pheretima Posthuma) }\end{array}$} \\
\hline & & & Time of Paralysis in min $(P)$ & Time of Death in $\min (\mathrm{D})$ \\
\hline \multirow{4}{*}{1} & \multirow{4}{*}{ Aqueous } & 25 & $25.90 \pm 1.22$ & $101.22 \pm 2.50$ \\
\hline & & 50 & $12.84 \pm 1.30$ & $41.05 \pm 2.30$ \\
\hline & & 75 & $4.20 \pm 1.25$ & $12.78 \pm 1.20$ \\
\hline & & 100 & $1.90 \pm 0.55$ & $11.15 \pm 1.50$ \\
\hline \multirow{4}{*}{2} & \multirow{4}{*}{ Aqueous + Acetone } & 25 & $22.50 \pm 1.20$ & $98.11 \pm 2.0$ \\
\hline & & 50 & $10.78 \pm 1.00$ & $38.31 \pm 2.15$ \\
\hline & & 75 & $2.50 \pm 1.35$ & $9.80 \pm 1.15$ \\
\hline & & 100 & $1.00 \pm 0.66$ & $8.20 \pm 1.20$ \\
\hline \multirow{4}{*}{3} & \multirow{4}{*}{ Petroleum Ether } & 25 & $27.50 \pm 1.15$ & $102.30 \pm 2.40$ \\
\hline & & 50 & $13.11 \pm 1.60$ & $42.50 \pm 2.25$ \\
\hline & & 75 & $5.15 \pm 1.30$ & $13.50 \pm 1.65$ \\
\hline & & 100 & $2.20 \pm 0.50$ & $12.00 \pm 1.40$ \\
\hline 4 & Control (Normal Saline) & - & - & - \\
\hline 5 & Standard (Piperazine citrate) & 10 & $9.12 \pm 0.75$ & $12.95 \pm 1.29$ \\
\hline
\end{tabular}


Nishant M Patel et al; Saudi J Med Pharm Sci, Nov. 2019; 5(11): 964-971

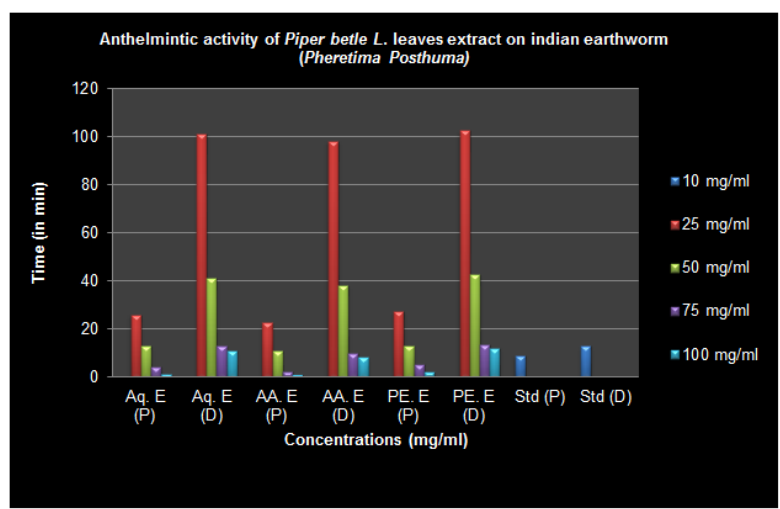

Graph-1: Anthelmintic activity of Piper betle $L$. leaves extracts on Indian earthworm (Pheretima Posthuma)

Aq. $\mathrm{E}=$ Aqueous Extract, $\mathrm{AA} . \mathrm{E}=$ Aqueous + Acetone Extract, PE. $\mathrm{E}=$ Petroleum Ether Extract, Std = Standard, $(\mathrm{P})=$ Paralysis Time, $(\mathrm{D})=$ Death Time

\section{RESULT}

From the above observations, higher concentration of extract produced paralytic effect much earlier and the time to death was shorter for all worms. All the extracts showed anthelmintic activity but Aqueous + Acetone extract showed better anthelmintic activity than other extracts, in dose-dependent manner giving shortest time of paralysis (P) and death (D) with $100 \mathrm{mg} / \mathrm{ml}$ concentration. Evaluation of anthelmintic activity was compared with reference standard Piperazine citrate.

From Table No. 6, it is observed that 100 $\mathrm{mg} / \mathrm{ml}$ conc. of leaves of Piper betle L. shown potent anthelmintic activity while 75,50 and $25 \mathrm{mg} / \mathrm{ml}$ conc. taken more time for paralysis as well as death of worms. The results are compared with the standard drug Piperazine citrate. For Aqueous + Acetone extract the time of paralysis $(\mathrm{P})$ was found to be $22.50,10.78,2.50$ and $1.00 \mathrm{~min}$. at conc. of $25,50,75$ and $100 \mathrm{mg} / \mathrm{ml}$ respectively when compared to standard i.e. Piperazine citrate $(9.12 \mathrm{~min}$.) at the conc. of $10 \mathrm{mg} / \mathrm{ml}$ and to normal saline as control. While the time of death (D) was found to be 98.11, 38.31, 9.80 and $8.20 \mathrm{~min}$. for Aqueous + Acetone extract, at conc. of 25, 50, 75 and $100 \mathrm{mg} / \mathrm{ml}$ respectively when compared to standard i.e. Piperazine citrate (12.95 min.) at the conc. of $10 \mathrm{mg} / \mathrm{ml}$ and to normal saline as control. The results obtained indicate that Aqueous + Acetone extract of Piper betel L. leaves shown significant anthelmintic activity at conc. of $100 \mathrm{mg} / \mathrm{ml}$ against Pheretima Posthuma. The results of anthelmintic activity are shown in Table No. 6 and the graphical representations of results were shown in Graph No.1.

\section{DISCUSSION}

Piper betle $L$. is widely use in the traditional system of medicine for the treatment of number of diseases. The results of these investigations would helpful for proper identification, collection and investigation of the plant. The parameters determined in quantitative microscopy can be helpful to differentiated closely related species. The presence of various phytoconstituents can serve to treat diseases by using various pharmacological activities. Physical standards may be used to determine the quality of this plant in future investigation. It will also helpful to carry out further research and revalidation of its use in traditional system in medicine.

It also gives anthelmintic activity and the experimental evidence obtained in the laboratory model could provide a rationale for the traditional use of this plant as anthelmintic. The plant may be further explored for its phytochemical profile to recognize the active constituent accountable for anthelmintic activity. Further studies using in vivo models are required to carry out and establish the effectiveness and pharmacological rationale for the use of Piper betle $L$. leaves as an anthelmintic drug. The drug can be further explored for the isolation and characterization of the active constituents responsible for anthelmintic activity.

\section{REFERENCES}

1. Sripradha, S. (2014). Betel leaf-the green gold. Journal of Pharmaceutical Sciences and Research, 6(1), 36.

2. Sengupta, R., \& Banik, J. K. (2013). A review on betel leaf (pan). International Journal of Pharmaceutical Sciences and Research,4(12), 4519.

3. Venkateswarlu, K., Devanna, N., \& Prasad, N. B. L. (2014). Microscopical and Preliminary Phytochemical Screening of 'Piper betel'. PharmaTutor, 2(4), 112-118.

4. Nagori, K., Singh, M. K., Alexander, A., Kumar, T., Dewangan, D., Badwaik, H., \& Tripathi, D. K. (2011). Piper betleL.: A review on its ethnobotany, phytochemistry, pharmacological profile and profiling by new hyphenated technique DART-MS (Direct Analysis in Real Time Mass Spectrometry). Journal of Pharmacy Research, 4(9), 2991-2997.

5. Sharma, J. D., Sharma, L., \& Yadav, P. (2007). Antifertility efficacy of Piper betle Linn.(Petiole) on female albino rats. Asian j. exp. Sci, 21(1), 145150.

6. Shantakumari, P., Prakasam, A., \& Pugalendi, K. V. (2006). Antihyperglycemic activity of P. betle on streptozotoan induces diabetic rats. Journal ofMedicinal Food, 9(1), 108-112.

7. Trakranrungsie, N., Chatchawanchonteera, A., \& Khunkitti, W. (2008). Ethnoveterinary study for antidermatophytic activity of Piper betle, Alpinia galanga and Allium ascalonicum extracts in vitro. Research in veterinary science, 84(1), 80-84.

8. Arambewela, L. S. R., Arawwawala, L. D. A. M., \& Ratnasooriya, W. D. (2005). Antidiabetic 
activities of aqueous and ethanolic extracts of Piper betle leaves in rats. Journal of Ethnopharmacology, 102(2), 239-245.

9. Garg, S. C., \& Jain, R. (1992). Biological activity of the essential oil of Piper betle L. Journal of Essential Oil Research, 4(6), 601-606.

10. http://www.wikipedia.org

11. Pradhan, D., Suri, K. A., Pradhan, D. K., \& Biswasroy, P. (2013). Golden heart of the nature: Piper betle L. Journal of Pharmacognosy and Phytochemistry, 1(6).

12. Pakrashi, S. C., \& Pakrashi, A. (2003). Ginger: A versatile healing herb. Vedams eBooks (P) Ltd.

13. http://monaconatureencyclopedia.com

14. Sugumaran, M., Poornima, M., Venkatraman, S., Lakshmi, M., \& Sethuvani, S. (2011). Chemical composition and antimicrobial activity of sirugamani 1 variety of Piper betle Linn leaf oil. $J$ Pharm Res, 4(10), 3424-3426.

15. Dwivedi, V., \& Tripathi, S. (2014). Review study on potential activity of Piper betle. J Pharmacogn Phytochem, 3(4), 93-98.

16. Chahal, J., Ohlyan, R., Kandale, A., Walia, A., \& Puri, S. (2011). Introduction, phytochemistry, traditional uses and biological activity of genus Piper: A review. International Journal of Current Pharmaceutical Review and Research, 2(2), 130144.
17. Pharmacopoeia, I. (1996). 4th edn., Vol. II, Government of India, Ministry of Health and Welfare.

18. Pharmacopoeia, I. (1996). Vol. II, Govt. of India, Ministry of Health and family welfare.

19. Pharmacopoeia, I. (1996). Vol. I, Government of India.

20. Khandelwal, K.R. (2002). Practical Pharmacognosy, Techniques and Experiments. Pune. Nirali Prakashan, 149-59

21. Ajaiyeoba, E. O., Onocha, P. A., \& Olarenwaju, O. T. (2001). In vitro anthelmintic properties of Buchholzia coriaceae and Gynandropsis gynandra extracts. Pharmaceutical biology, 39(3), 217-220.

22. McMillan, B. (1971). Parasitology (Protozoology and Helminthology). Pathology, 3(1), 83.

23. Vigar, Z. (1984). Atlas of medical parasitology.

24. Sollmann, T. (1918). Anthelmintics: Their efficiency as tested on earthworms. Journal of Pharmacology and Experimental Therapeutics, 12(3), 129-170.

25. Kokate, C. K. (1994). Practical Pharmacognosy. Pune. Nirali Prakashan, 115-20, 24-28.

26. Mukherjee, P. K. (2002). Quality control of herbal drugs: an approach to evaluation of botanicals. Business Horizons.

27. Kokate, C.K. (1984). Practical Pharmacognosy. New Delhi. Vallabh Prakashan, 107- 113. 